\title{
Nutrient intakes of urban dwellers in Lagos, Nigeria
}

\author{
By JOHN McFIE \\ Ministry of Health, Lagos, Nigeria \\ (Received 10 March I966-Accepted I I Fanuary 1967)
}

\begin{abstract}
I. The nutrient contents of diets consumed by families in the lower income groups in Lagos are compared with published values for diets consumed by Nigerians in rural areas.

2. Qualitatively, the dietary patterns of urban dwellers tended to resemble those of the regions from which they had migrated; attention is drawn to certain exceptions.

3. Quantitatively, urban diets resembled those in rural areas in (a) providing a lower proportion, in relation to requirements, of calories rather than of protein; and $(b)$ allowing children lower intakes of all nutrients, in relation to requirements, than adults.

4. Restriction of calorie intake resulted in diversion of dietary protein to energy production, and this in turn led to low mean body-weights of children and of adults.
\end{abstract}

During the past Io years, a number of studies have appeared on the diets of rural populations in Nigeria. Nicol (I959a,b) reported the results of surveys in seven villages, mainly in the drier northern part of the country; Collis, Dema \& Omololu (1962) have reported results from four villages in the western part of the southern forest belt; and Ekpo ( 1964$)$ has reported results from three villages in the eastern part of the forest belt.

The results of these surveys are not directly comparable, since Nicol's observations are grouped in selected age-groups, and Collis et al. and Ekpo present their results on a per caput basis. Nevertheless, an approximate comparison of the three sets of results may be made in terms of the percentage of the recommended allowances of nutrients provided by each diet. The authors' values for calorie and protein intakes, as percentages of requirement (FAO, 1957a) and of safe practical allowance (FAO, $1957 b$ ) respectively, are summarized in Table $\mathrm{I}$.

Examination of these values shows two noteworthy features, in comparisons between calorie and protein intakes, and in comparisons between dietary intakes of adults and children. In all the Northern groups, whose staple foods are grains, protein intake, relative to recommended allowances, is higher than calorie intake; in all save one of the Southern groups, where the staples are starchy roots, calorie intake, relative to recommended allowances, is higher than protein intake. Secondly, in all those groups for whom results are available separately for adults and children, the intakes, relative to requirements, of both calories and protein are lower for children than for adults. As Nicol (I959a) stated: 'The parents in most of rural Nigeria do not realize the needs of growing children.'

Comparable evidence of the incidence of malnutrition is not presented in these studies, but the state of nutrition of the children may be inferred from their weights. Nicol (1959a) reported the mean weights of children in three age-groups; these may be compared with standard weights from a community not affected by malnutrition or parasitic diseases, e.g. the English norms by Tanner (1958). The overall averages 
Table I. Percentage of requirements* provided by dietary intake in Nigerian villages

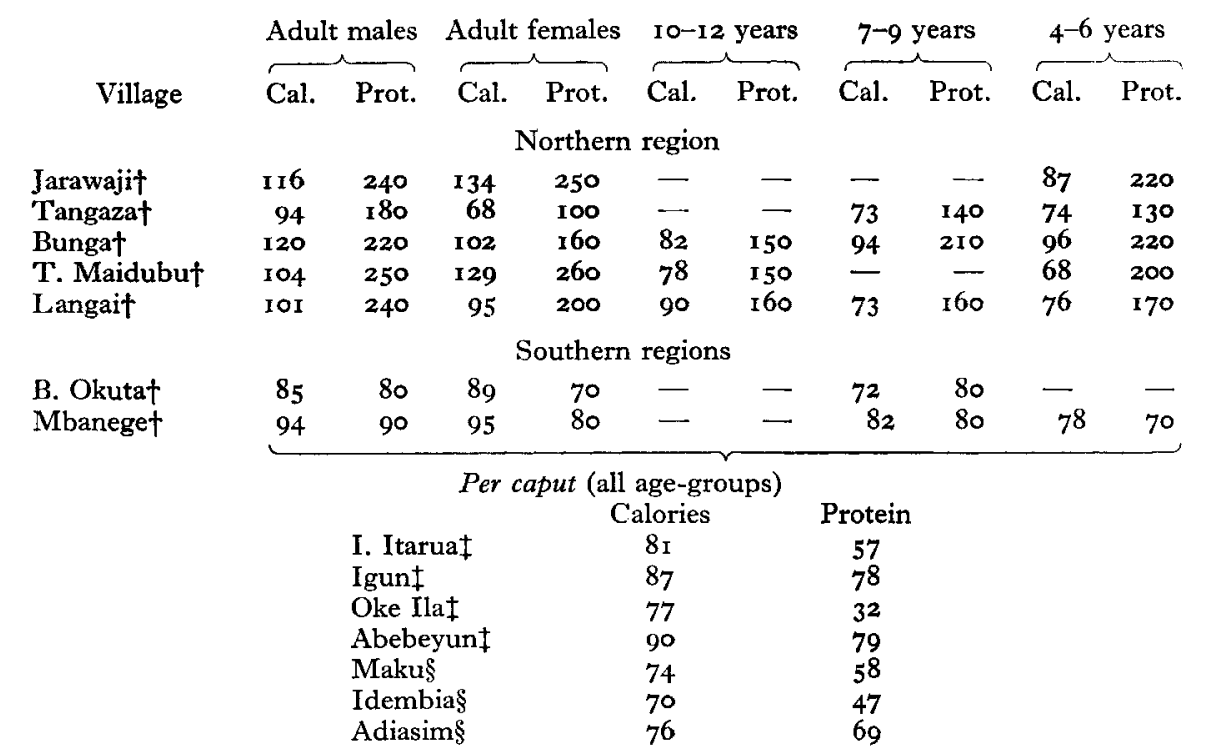

* Calorie (Cal.) requirements (FAO, r957a); safe practical allowances of protein (Prot.) (FAO, $1957 b)$.

† From Nicol (1959a, b).

I From Collis, Dema \& Omololu (1962).

$\S$ From Ekpo (1964).

for the children reported by Nicol, expressed as percentages of the weights of the 5oth percentile of English children of 5,8 and I I years respectively, are:

$\begin{array}{ccc}4-6 \text { years } & 7-9 \text { years } & \text { 10-12 years } \\ 85 & 91 & 93\end{array}$

Commenting on the measurements, Nicol suggested that 'in determining height and weight of the children a greater part is played by the intake of calories than by the amount of protein in the diet, provided that the deficiency of protein, quantitative or qualitative, is not severe'.

Collis et al. (I962) and Ekpo (1964) presented the measurements of children graphically, comparing them with those of an 'optimum' Nigerian group which 'fitted the curves given by Nelson for American children'. The mean weights and heights of the children in both studies fall well below the 'optimum' standard. Commenting on these values, Ekpo (1964) observes that 'by relating (the growth data) to the data on food intakes, it can be seen that in general, the better the diet of a village, the more the physique of the children approaches that of their mates in the well-to-do Nigerian families'.

There is evidence, then, of considerable variation in the nutrient intakes in rural areas in different parts of Nigeria, which is largely determined by the nature of the foodstuffs grown locally. In all these areas, moreover, there is evidence that the 
nutrient intake of children, particularly in relation to their calorie requirements, is poorer than that of adults.

The populations of the towns of Nigeria consist largely of immigrants from rural areas, and it is of some interest, as well as of practical value, to ascertain the nature of the diets of the immigrants from different parts of Nigeria. This paper reports the results of a survey carried out among families in Lagos, a city of more than 600000 inhabitants, in 1964 .

\section{METHODS}

The people studied. These were not selected on a random basis. One of the aims of the survey was to ascertain the diets of children; another was to include representatives of the three main regions of Nigeria, the North, the East and the West; and our interest was in general limited to the lower income stratum of the population. The majority of our families were selected from those in the child health study being conducted by the Lagos University Institute of Child Health; these had been selected from the Lagos births register. There were, however, few families of Northern origin in this group, and additional families were selected from the records of the child welfare clinic conducted in a suburb in which Northerners have settled. Twelve families were also studied in Akpese, a fishing village within the boundaries of Lagos.

Table 2. Age (years) distribution of male $(M)$ and female $(F)$ Lagos subjects surveyed

\begin{tabular}{|c|c|c|c|c|c|c|c|c|c|c|c|c|c|c|c|c|c|}
\hline & \multicolumn{3}{|c|}{ Under I } & \multicolumn{2}{|c|}{$I-9$} & \multicolumn{2}{|c|}{$10-19$} & \multicolumn{2}{|c|}{$20-29$} & \multicolumn{2}{|c|}{$3^{0}-39$} & \multicolumn{2}{|c|}{$40-49$} & \multicolumn{2}{|c|}{$5^{\circ}-59$} & \multicolumn{2}{|c|}{ Over 60} \\
\hline & $\begin{array}{c}\text { Region of } \\
\text { origin }\end{array}$ & $\overbrace{M}$ & $\mathrm{~F}$ & $\overbrace{\mathrm{M}}$ & $\mathbf{F}$ & $\overbrace{\mathbf{M}}$ & F & $\overbrace{M}$ & F & $\overbrace{\mathrm{M}}$ & F & $\overparen{M}$ & F & M & F & $\overbrace{\mathbf{M}}$ & $\mathrm{F}$ \\
\hline \multirow[t]{2}{*}{ Surulere } & Eastern & . & . & 4 & 5 & 2 & 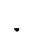 & 2 & 3 & $\mathbf{I}$ & 2 & . & . & - & . & . & . \\
\hline & Western & 3 & 2 & 16 & 14 & 4 & 4 & 3 & 4 & 2 & 3 & $\mathbf{I}$ & . & . & - & . & I \\
\hline \multirow[t]{2}{*}{ Obalende } & Northern & $\mathbf{I}$ & 3 & 6 & 6 & 3 & $\mathbf{I}$ & . & 3 & 4 & 4 & I & $\mathbf{I}$ & $\mathbf{I}$ & . & . & I \\
\hline & Western & • & . & 6 & 2 & 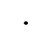 & I & $\mathbf{I}$ & $\mathbf{I}$ & & . & . & 3 & $\mathbf{I}$ & I & . & . \\
\hline Lagos Island & Western & 2 & 7 & I4 4 & 17 & 6 & 6 & 2 & 9 & 2 & I I & I & $\mathbf{I}$ & . & . & $I$ & I \\
\hline \multirow[t]{2}{*}{ Mushin } & Eastern & $\mathbf{I}$ & $\mathbf{I}$ & 5 & I I & 2 & 3 & 2 & 4 & $\mathbf{I}$ & 2 & . & . & . & . & . & . \\
\hline & Western & . & . & 5 & 4 & 4 & 2 & $\mathbf{I}$ & 3 & . & 3 & I & $\mathbf{I}$ & . & . & . & . \\
\hline \multirow[t]{2}{*}{ Akpese } & Western & . & . & 6 & 4 & I & 2 & 3 & I & 2 & 3 & 2 & I & . & . & I & I \\
\hline & Other* & I & 2 & 6 & 7 & 4 & 2 & 4 & 5 & $\mathbf{I}$ & I & I & . & . & . & I & . \\
\hline
\end{tabular}

* Ghanaian and Togolese immigrants.

The families were grouped in five residential areas:

Surulere, a recently built suburb, including families rehoused from older parts of Lagos; the families were of Eastern or of Western origin.

Obalende, a suburb of intermediate age; the families were of Northern and of Western origin.

Lagos Island, the oldest part of Lagos; the families were all of Western origin, and many were permanent residents of Lagos.

Mushin, just outside the boundary of Lagos, a suburb of intermediate age; the families were of Eastern and Western origin.

Akpese, the fishing village mentioned above; some families were of Western origin, others were immigrant fishermen from Ghana and Togo. 
The age distribution of the population in the five suburbs is shown in Table 2: many of the women lived apart from the fathers of their children, and the majority of them carried on petty trade in addition to household work.

Food consumption. In each household, food consumption was studied for 7 consecutive days. No significant difference was found between the quantities consumed on the first or last days and any of the other 5 days of the survey. Weights and costs were recorded of foodstuffs prepared for cooking, of the cooked food, and of each subject's portion and plate waste. Recording was carried out by trained staff of the Nutrition Service and of the Institute of Child Health.

A feature of dietary habits in Lagos is the custom of purchasing food ready-cooked from food sellers; in this survey $47 \%$ of meals were thus purchased. The householder distributes money for these purchases to each member of the family, who usually returns to the home to eat what he has bought. It was therefore possible to weigh most of the purchased portions, and also to ascertain the prevailing cost/oz of cooked foods in each area. Samples of these were purchased to enable the proportions of the ingredients to be weighed, and the moisture content to be assessed by the Government Chemist. For those foods eaten outside the home, quantities were inferred from their cost.

A consequence of the custom of purchasing ready-cooked food was that each person had a portion of his own; and this applied also to most of the meals prepared at home. As a result, our records of food consumption were obtained on an individual, rather than a per caput, basis.

Examination. All subjects were weighed, barefoot, on a spring balance checked against government-inspected weights. Ages of adults were ascertained by questioning, but for most of the children birth certificates were available. Clinical examination followed the methods recommended by WHO (1963).

\section{RESULTS}

Food consumption. The mean daily food intakes of the same age-groups as those used by Nicol (1959a) are shown in Table 3 .

Requirements have been calculated as follows: calories, from the Report of the FAO Committee (FAO, 1957a); protein, from the Report of the FAO Committee (FAO, I957b); calcium, from the Report of the FAO Committee (FAO, I962); other nutrients from the requirements suggested by the British Medical Association (1950). The mean percentage of requirements provided by the daily food intake is shown in Table 4. A general feature of the diets of all age-groups was their high content of vitamin $\mathrm{A}$ and ascorbic acid, owing to the frequent use of palm oil and of fresh vegetables, plantains and yams; on the other hand, the values for calcium and riboflavine were consistently low.

Comparison of the adequacy of the energy and protein content of these diets with those summarized in Table $\mathrm{I}$ shows that, in general, their low values resembled those of the villages in the two Southern regions rather than those of the North, except that in every instance the calorie value in relation to requirements of the urban diets is 
lower than the protein value. When the values for different age-groups are compared with those reported by Nicol (1959a,b), it will be seen that there was the same general trend in that intakes, relative to requirements, were higher for adults than for children. Also in Lagos the diets of younger children (4-6 years of age) tended to be more nearly adequate than those of the older ones (IO-I 2 years).

Table 3. Mean daily food intakes ( $\mathrm{g}$ ) of Lagos subjects

\begin{tabular}{|c|c|c|c|c|c|c|}
\hline \multirow[b]{2}{*}{ Foodstuff } & \multirow[b]{2}{*}{$\begin{array}{l}\text { Adult } \\
\text { males }\end{array}$} & \multirow[b]{2}{*}{$\begin{array}{c}\text { Aduit } \\
\text { females }\end{array}$} & \multirow{2}{*}{$\begin{array}{l}\text { Pregnant } \\
\text { and } \\
\text { lactating } \\
\text { women }\end{array}$} & \multicolumn{3}{|c|}{ Children } \\
\hline & & & & $\begin{array}{l}\text { IO-I } 2 \\
\text { years }\end{array}$ & $\begin{array}{c}7-9 \\
\text { years }\end{array}$ & $\begin{array}{c}4-6 \\
\text { years }\end{array}$ \\
\hline Maize flour & 50 & 46 & 47 & 26 & 17 & 23 \\
\hline Rice & 54 & 57 & 70 & 35 & 57 & 54 \\
\hline Sorghum & 7 & I & 18 & 8 & 2 & 4 \\
\hline Bread & 40 & 47 & I 8 & 13 & 15 & 17 \\
\hline Acca* & 2 & - & 6 & - & 2 & I \\
\hline Cassava gari & 221 & I 34 & 177 & 135 & 109 & 84 \\
\hline Yam: fresh & 83 & $9 \mathrm{I}$ & 130 & 45 & 72 & 73 \\
\hline flour & $一$ & IO & 20 & 4 & 10 & I I \\
\hline Plantain & II & 9 & I3 & 6 & I I & 15 \\
\hline Cowpeas & $4 I$ & 35 & 47 & 33 & 40 & 34 \\
\hline Bean caket & 2 & $\mathbf{I}$ & 2 & $\mathbf{I}$ & $\mathbf{I}$ & $\mathbf{I}$ \\
\hline Groundnuts & $\mathbf{I}$ & 一 & I & - & I & I \\
\hline Pumpkin seed & 5 & 4 & 5 & 3 & 2 & 2 \\
\hline Green leaves & 12 & Io & 12 & 8 & 7 & 8 \\
\hline Peppers $\ddagger$ & 21 & 17 & 22 & 12 & I5 & 13 \\
\hline Other vegetables & 25 & 22 & $3^{I}$ & 19 & 22 & 23 \\
\hline Fresh fruit & 5 & 5 & 2 & - & $\mathbf{I}$ & 2 \\
\hline Meat and fowl & 52 & 43 & $5^{6}$ & 23 & 18 & 17 \\
\hline Fish: fresh & IIO & 49 & 60 & 20 & 26 & 17 \\
\hline dried & 7 & 8 & 7 & 2 & 3 & 3 \\
\hline Crab & 20 & 3 & 8 & $\mathbf{I}$ & 2 & 2 \\
\hline Eggs & 7 & 4 & 4 & 3 & 2 & 2 \\
\hline Milk: fresh & 2 & 一 & 6 & - & $一$ & 2 \\
\hline evaporated & 6 & 13 & 8 & 2 & 2 & 5 \\
\hline Margarine & - & $\mathbf{I}$ & - & I & - & - \\
\hline Palm oil & 24 & 16 & 24 & 17 & $2 I$ & 19 \\
\hline Groundnut oil & 5 & 4 & I I & $\mathbf{I}$ & 2 & 2 \\
\hline Sugar & 5 & 10 & 7 & 2 & $\mathbf{I}$ & 3 \\
\hline Beer & 20 & - & - & - & - & - \\
\hline
\end{tabular}

Foodstuffs whose mean daily intake was less than $\mathrm{I}$ g included sweet potato, dika nut, coconut, corned beef, snails and cocoa powder (or Ovaltine).

* Digitaria. † Parkia. † Capsicum. \& Bottled lager (ml).

Region of origin. Although the method of selection of the families studied resulted in particular attention to the lower income groups, there was inevitably some variation in economic status, with a tendency for families of the same economic levels to live in the same suburb. Thus many of the inhabitants of Surulere were in clerical occupations; those in Obalende, Lagos Island and Mushin were petty traders or unskilled workers, and those in Akpese were fishermen. The average daily expenditure per head on food ranged from $2 s .5 d$. in Obalende to $1 s .4 d$. in Lagos Island; in Akpese it was only $9 d$., but the fish eaten was part of their daily catch.

A much greater variation, however, was associated with the region of origin of the families. With the exception of a few Lagos families, all the adults in this survey 
were immigrants from one or other of the regions, and were classified accordingly. The Lagos families, being of the same ethnic stock, were classified as of Western origin. The variation is illustrated by the mean daily food intakes of adult females from four of the five suburbs, shown in Table 5. The Northerners consumed more cereal grains than those from the two Southern regions; they also consumed more meat, and are the only group that consumed fresh milk.

Table 4. Daily nutrient intakes of people in Lagos consuming the diets summarized in Table 3

\begin{tabular}{|c|c|c|c|c|c|c|c|c|c|}
\hline Age-group & $\begin{array}{r}\text { Calories } \\
\text { (kcal) }\end{array}$ & $\begin{array}{l}\text { Protein } \\
\text { (g) }\end{array}$ & $\begin{array}{l}\text { Calcium } \\
\text { (mg) }\end{array}$ & $\begin{array}{l}\text { Iron } \\
\text { (mg) }\end{array}$ & $\begin{array}{c}\text { Vitamin } \\
\text { A } \\
\text { (i.u.) }\end{array}$ & $\begin{array}{l}\text { Thia- } \\
\text { mine } \\
\text { (mg) }\end{array}$ & $\begin{array}{c}\text { Ribo- } \\
\text { flavine } \\
\text { (mg) }\end{array}$ & $\begin{array}{l}\text { Nico- } \\
\text { tinic acid } \\
(\mathrm{mg})\end{array}$ & $\begin{array}{c}\text { Ascorbic } \\
\text { acid } \\
\text { (mg) }\end{array}$ \\
\hline Adult males & $\begin{array}{r}2010 \\
77\end{array}$ & $\begin{array}{r}71 \\
\mathbf{r 2 8}\end{array}$ & $\begin{array}{r}355 \\
88\end{array}$ & $\begin{array}{r}12 \cdot 3 \\
154\end{array}$ & $\begin{array}{r}16700 \\
33^{\circ}\end{array}$ & $\begin{array}{r}0.9 \\
75\end{array}$ & $\begin{array}{r}0.6 \\
33\end{array}$ & $\begin{array}{r}14 \cdot 1 \\
108\end{array}$ & $\begin{array}{l}107 \\
530\end{array}$ \\
\hline Adult females & $\begin{array}{r}1610 \\
78\end{array}$ & $\begin{array}{r}54 \\
\text { 108 }\end{array}$ & $\begin{array}{r}314 \\
78\end{array}$ & $\begin{array}{r}10 \cdot 7 \\
134\end{array}$ & $\begin{array}{r}\text { I I } 400 \\
230\end{array}$ & $\begin{array}{l}0.8 \\
80\end{array}$ & $\begin{array}{r}0.5 \\
33\end{array}$ & $\begin{array}{l}10 \cdot 0 \\
100\end{array}$ & $\begin{array}{r}86 \\
430\end{array}$ \\
\hline $\begin{array}{l}\text { Pregnant and } \\
\text { lactating women }\end{array}$ & $\begin{array}{r}2062 \\
66\end{array}$ & $\begin{array}{l}63 \\
65\end{array}$ & $\begin{array}{r}379 \\
\mathbf{3 8}\end{array}$ & $\begin{array}{r}15 \cdot 0 \\
100\end{array}$ & $\begin{array}{r}16900 \\
240\end{array}$ & $\begin{array}{l}I \cdot I \\
84\end{array}$ & $\begin{array}{l}0.6 \\
30\end{array}$ & $\begin{array}{r}12 \cdot 3 \\
95\end{array}$ & $\begin{array}{l}\text { I16 } \\
230\end{array}$ \\
\hline \multicolumn{10}{|l|}{ Children: } \\
\hline I0-12 years & $\begin{array}{r}114 I \\
55\end{array}$ & $\begin{array}{l}31 \\
63\end{array}$ & $\begin{array}{r}\mathbf{I} 93 \\
32\end{array}$ & $\begin{array}{r}7.0 \\
58\end{array}$ & $\begin{array}{r}\text { I I } 400 \\
250\end{array}$ & $\begin{array}{r}0.6 \\
50\end{array}$ & $\begin{array}{l}0.3 \\
20\end{array}$ & $\begin{array}{r}5 \cdot 8 \\
48\end{array}$ & $\begin{array}{r}61 \\
102\end{array}$ \\
\hline 7-9 years & $\begin{array}{r}1207 \\
61\end{array}$ & $\begin{array}{l}33 \\
83\end{array}$ & $\begin{array}{r}201 \\
40\end{array}$ & $\begin{array}{r}7 \cdot 6 \\
76\end{array}$ & $\begin{array}{r}13600 \\
390\end{array}$ & $\begin{array}{r}0.7 \\
70\end{array}$ & $\begin{array}{r}0.4 \\
27\end{array}$ & $\begin{array}{r}6 \cdot 3 \\
63\end{array}$ & $\begin{array}{r}77 \\
\mathbf{1 2 8}\end{array}$ \\
\hline $4-6$ years & $\begin{array}{r}\text { I } 134 \\
68\end{array}$ & $\begin{array}{l}30 \\
94\end{array}$ & $\begin{array}{r}202 \\
50\end{array}$ & $\begin{array}{r}7 \cdot 8 \\
97\end{array}$ & $\begin{array}{r}12300 \\
490\end{array}$ & $\begin{array}{r}0.6 \\
75\end{array}$ & $\begin{array}{r}0.3 \\
25\end{array}$ & $\begin{array}{r}5.4 \\
68\end{array}$ & $\begin{array}{r}69 \\
138\end{array}$ \\
\hline
\end{tabular}

Values in bold-face type represent percentage of requirements (see p. 260).

For the groups of Western origin, the staple foods were primarily starchy roots; the better-off (those in Obalende and Akpese) consumed larger quantities of these and also of other foods. Comparison of the group of Eastern origin with those of Western origin in the same suburb (Mushin) shows that, though the patterns of food consumption were very similar, the former tended to consume larger quantities than the latter. The wives of fishermen in Akpese consumed, as might be expected, the greatest amounts of fish; their staple food was largely cassava gari.

The nutrient values of those diets are shown in Table 6 . In outline, they resemble the general pattern shown in Table 4; high levels of vitamin A and ascorbic acid, low levels of calcium and riboflavine, and calorie intake lower in relation to requirements than protein intake. Particular contrasts between groups may be associated with features of the dietary intake; the consumption of fish in Akpese provided high levels of protein and nicotinic acid, and the difference between the two groups in consumption of grains was reflected in variation in iron intake. In Mushin, the larger quantities consumed by the Easterners, in particular of meat and fish, resulted in intakes nearer to adequacy in respect of protein, iron, thiamine and nicotinic acid. For the poorer Westerners, in Lagos Island and in Mushin, the dietary intake was low of all nutrients excepting vitamin A and ascorbic acid.

The proportions of foodstuffs consumed by other members of the family generally 
resembled those consumed by the mother; between members, variations in overall quantities were more significant than those in individual foods. Moreover, the nutrients least likely to reach adequate levels were calories, protein, calcium and riboflavine. These relationships are illustrated in Table 7 , in which the values for these four nutrients are shown for the diets of adults and children in the ethnic groups with the highest and the lowest food consumptions. It will be seen that the values for adult females, in relation to requirements, were not significantly lower than those for adult

\section{Table 5. Mean daily food intakes $(g)$ of adult females of Northern, Western or Eastern origin living in four areas of Lagos}

\begin{tabular}{|c|c|c|c|c|c|c|c|}
\hline \multirow[b]{2}{*}{ Foodstuff } & \multicolumn{2}{|c|}{ Obalende } & \multirow[b]{2}{*}{$\begin{array}{l}\text { Island } \\
\text { Western } \\
\text { origin } \\
\text { (4) }\end{array}$} & \multicolumn{2}{|c|}{ Mushin } & \multicolumn{2}{|c|}{ Akpese } \\
\hline & $\begin{array}{l}\text { Northern } \\
\text { origin } \\
\text { (5) }\end{array}$ & $\begin{array}{l}\text { Western } \\
\text { origin } \\
\text { (3) }\end{array}$ & & $\begin{array}{l}\text { Western } \\
\text { origin } \\
\text { (3) }\end{array}$ & $\begin{array}{l}\text { Eastern } \\
\text { origin } \\
(4)\end{array}$ & $\begin{array}{l}\text { Western } \\
\text { origin } \\
(4)\end{array}$ & $\begin{array}{l}\text { Other* } \\
\text { origin } \\
(3)\end{array}$ \\
\hline Maize flour & 82 & $7 I$ & 47 & 50 & IO & 48 & 12 \\
\hline Rice & 205 & 48 & 49 & 35 & $9 \mathrm{I}$ & 30 & I 8 \\
\hline Sorghum & $\mathbf{3 2}^{2}$ & - & 4 & - & $\longrightarrow$ & - & - \\
\hline Bread & 23 & 47 & 42 & 63 & 26 & $x 6$ & 3 \\
\hline Acca & 33 & - & - & - & - & - & - \\
\hline Cassava gari & $6_{3}$ & $15 \mathrm{I}$ & 160 & $x+8$ & 170 & 187 & I I I \\
\hline Yam: fresh & 231 & 156 & 49 & 5 & 73 & 105 & 33 \\
\hline flour & 43 & 15 & 12 & - & 21 & - & - \\
\hline Plantain & - & 3 & 20 & 8 & I6 & - & I7 \\
\hline Cowpeas & 73 & 22 & 9 & $3 I$ & 24 & 45 & r6 \\
\hline Bean cake & 7 & $\mathbf{I}$ & - & I & - & $\mathbf{I}$ & - \\
\hline Groundnuts & 4 & 一 & 一 & I & $\mathbf{I}$ & - & - \\
\hline Pumpkin seed & 9 & 9 & 6 & 3 & 6 & ro & - \\
\hline Green leaves & 43 & 19 & 9 & 5 & 5 & I5 & - \\
\hline Peppers & 40 & 16 & 12 & 18 & 12 & 16 & 25 \\
\hline Other vegetables & 52 & I 8 & 12 & 25 & 26 & 24 & 35 \\
\hline Fresh fruit & 20 & 一 & - & 4 & - & - & 6 \\
\hline Meat and fowl & I 5 I & 48 & 26 & 39 & $4 I$ & 49 & 8 \\
\hline Fish: fresh & $2 I$ & 65 & 42 & 33 & 63 & I 6 & 151 \\
\hline dried & I & 5 & 16 & 2 & 4 & IO & 9 \\
\hline Crab & - & - & - & - & 一 & I & $7 I$ \\
\hline Eggs & 4 & - & - & 6 & - & 5 & 一 \\
\hline Milk: fresh & 33 & - & - & $一$ & 一 & - & - \\
\hline evaporated & 14 & I 6 & I 8 & 17 & 12 & I I & - \\
\hline Palm oil & 40 & 23 & 12 & I5 & 19 & 18 & 27 \\
\hline Groundnut oil & II & 5 & 5 & 4 & 2 & 4 & 2 \\
\hline Sugar & 13 & 2 & 5 & 12 & 9 & 4 & $\mathbf{I}$ \\
\hline
\end{tabular}

Figures in parentheses are the numbers of subjects.

* Ghanaian and Togolese immigrants.

males and may in fact have been higher. The nutrient intake of lactating females was higher than of those not lactating, but was not sufficient to meet the increased requirements. For the children, in spite of their lower total requirements, nutrient intakes were generally not sufficient to reach even the levels, in relation to requirements, reached by the adults. An exception was the group of pre-school Northern children, whose greater intakes of all nutrients were due principally to the amount of milk they were given; their mean daily intake was $35 \mathrm{~g}$ fresh and $18 \mathrm{~g}$ evaporated milk. In the same suburb, Obalende, none of the Western pre-school children was 


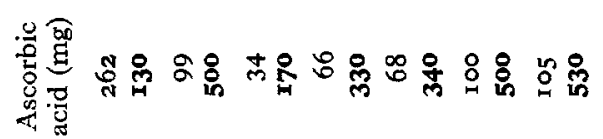

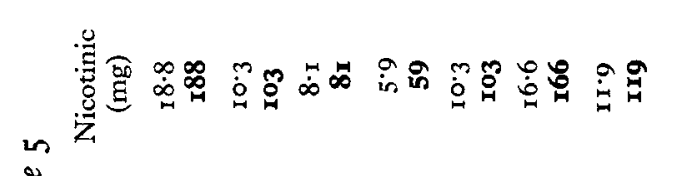

है

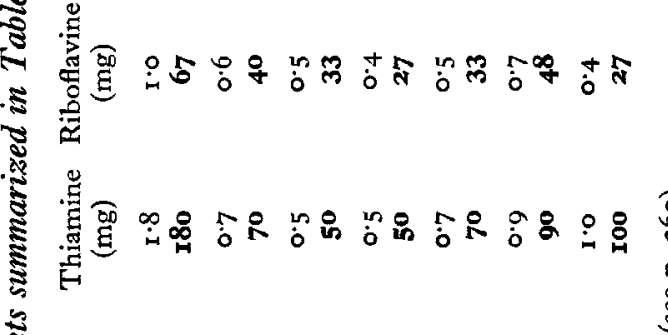

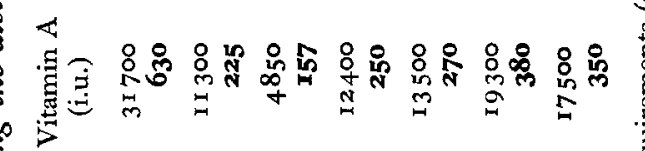

.

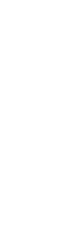

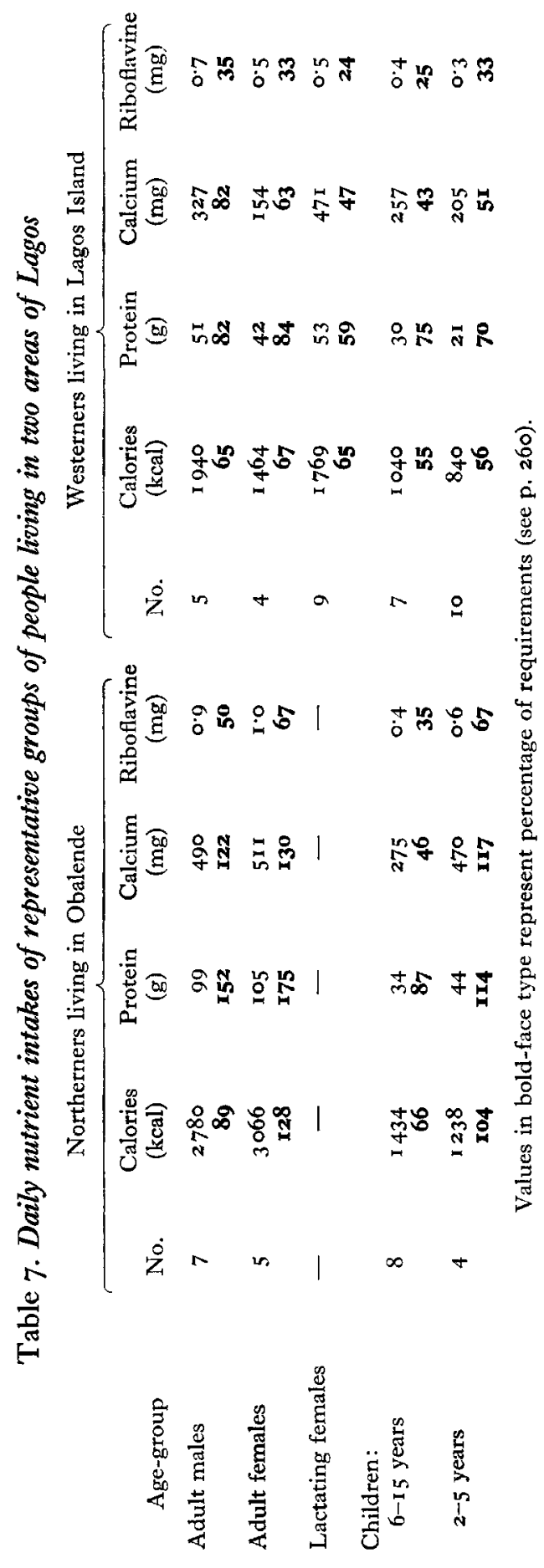


given milk. In the other suburbs, of fifty-eight pre-school children thirty-two were given no milk; the twenty-six who were given milk consumed on average in $\mathbf{g}$ evaporated milk daily.

Clinical signs and weights. The incidence of signs of malnutrition and of splenomegaly, and mean weights of the children between $\mathrm{I}$ and 9 years of age are shown in Table 8 , in which children of Western origin are compared with those from other regions. In addition, there were two boys with angular stomatitis aged IO-II, one of Western and one of Northern origin (the latter had also magenta tongue). It will be seen that signs of malnutrition were commoner among Western than among the other children, and that with one exception the mean weights of Western children were below those of the others. For comparison with Nicol's (1959a) values, the weights of the Lagos children, expressed as percentage of the standard weight, have been grouped in the same ages, giving the following means:

$\begin{array}{ccc}4-6 \text { years } & 7-9 \text { years } & \text { 10-12 years } \\ 90 & 95 & 94\end{array}$

Comparison with Nicol's values, quoted on p. 258 , shows that although the average for the youngest group was slightly higher in Lagos, the other two groups were not markedly different.

Table 8. Clinical signs (no. of children affected) and weights of Lagos children aged I-9 years

$\begin{array}{ccccccccc}\mathbf{1} & 2 & 3 & 4 & 5 & 6 & 7 & 8 & 9 \\ \text { year } & \text { years } & \text { years } & \text { years } & \text { years } & \text { years } & \text { years } & \text { years } & \text { years }\end{array}$

Children originating in Western region

\begin{tabular}{|c|c|c|c|c|c|c|c|c|c|}
\hline Total no. examined & 5 & I4 & 17 & 8 & 7 & 9 & 6 & I I & 6 \\
\hline Hair sparse, discoloured & 2 & 4 & 3 & $\mathbf{I}$ & & - & - & - & - \\
\hline Angular stomatitis & - & - & I & 2 & I & $\mathbf{I}$ & - & 2 & - \\
\hline Nutritional oedema & $\mathbf{I}$ & I & - & - & - & - & - & - & - \\
\hline Marasmus & 2 & — & - & - & - & - & - & - & - \\
\hline Palpable spleen & $\mathbf{I}$ & 2 & I & - & $\mathbf{I}$ & - & - & - & - \\
\hline Mean weight $(\mathrm{kg})$ & $8 \cdot 2$ & 10.9 & I $2 \cdot 2$ & I3.5 & $16 \cdot I$ & $18 \cdot 0$ & 20.8 & $22 \cdot 4$ & $25 \cdot 9$ \\
\hline Percent of standard weight & 82 & 87 & 84 & 82 & 87 & 90 & 95 & 93 & 98 \\
\hline
\end{tabular}

Children originating in other regions

Total no. examined

Hair sparse, discoloured

Angular stomatitis

Nutritional oedema

Palpable spleen

Mean weight $(\mathrm{kg})$

Percent of standard weight

$\begin{array}{ccccccccc}9 & 9 & 6 & 4 & 4 & 7 & 4 & 4 & 7 \\ 2 & \text { I } & \text { I } & - & - & - & - & - & - \\ - & - & - & - & - & \text { I } & - & - & \text { I } \\ \text { I } & - & - & - & - & - & - & - & - \\ 2 & \text { I } & - & \text { I } & - & - & - & - & - \\ 8 \cdot 4 & \text { II'2 } & \text { I3.7 } & \text { I4.0 } & \text { I6.6 } & 20 \cdot 4 & 20 \cdot 3 & 23 \cdot 0 & 26 \cdot 8 \\ 84 & 89 & 94 & 85 & 90 & \text { IO2 } & 92 & 96 & \text { IOI }\end{array}$

The mean weights of adults are shown in Table 9, in which it is evident that those of Western origin tended to have lower weights than those from other regions; the mean weight of the Northern women whose diets are summarized in Table 5 was $75.7 \mathrm{~kg}$. At the same time it will be noted that the mean weights of lactating women of both groups were lower than those of the non-lactating groups. Comparison with the mean weights of adults in rural areas given by Nicol (1959a) shows that in the majority of villages, adult weights were below those in the present study. 
Table 9. Mean weights ( $k g)$ of Lagos adults, 20-59 years

\begin{tabular}{|c|c|c|c|c|}
\hline & \multicolumn{2}{|c|}{$\begin{array}{c}\text { Originating in } \\
\text { Western region }\end{array}$} & \multicolumn{2}{|c|}{$\begin{array}{l}\text { Originating in } \\
\text { other regions }\end{array}$} \\
\hline & No. & Weight & No. & Weight \\
\hline Males & I I & $62 \cdot 2$ & 12 & $70 \cdot 7$ \\
\hline Females & 14 & 54.9 & 12 & $70 \cdot 1$ \\
\hline Lactating females & 17 & $52 \cdot 9$ & 8 & $58 \cdot 3$ \\
\hline
\end{tabular}

\section{DISCUSSION}

In rural areas of Nigeria, there is a clear distinction between the dietary patterns of those living in the northern savannahs and those in the southern forest belt. In the North the staple foods are cereal grains, and the relatively high cattle population allows a fair consumption of meat and of milk. In the South the staples are mainly starchy roots, and cattle are less plentiful; on the other hand, fish is more easily available than in the North. These variations determine the relative nutrient values of the household diets; within the family, however, from whichever region, the distribution of the food is such that the children usually obtain a smaller percentage of their requirements than do the adults.

Within the Southern forest belt, there is evidently considerable variation in nutrient values of diets, in spite of the generally starchy staples. Of the groups studied by Nicol, those in the Eastern region tended to consume larger quantities of most foods, and their mean body-weights were greater than of those in the Western part. Comparing the diets shown by Collis et al. (1962) in Western villages with those of Ekpo (1964) in Eastern villages, the Westerners tended to consume more plantains, cowpeas and meat, whereas the Easterners ate more yam, green leaves and dried fish. In none of the diets reported, save in the northernmost of Nicol's villages, near a rice-growing area, does rice appear as a significant item of the diet. Refined (imported) sugar appears in significant amounts in only two dietaries, both of Northerners, fresh fish in two (Northern) villages, wheat bread in three (Southern) villages, and evaporated milk not at all.

Comparison of the diets outlined above with the overall means of the Lagos subjects (Table 3) shows that in Lagos rice, wheat bread, fresh fish, evaporated milk and sugar appear as significant items. Fish is plentiful locally; bread, evaporated milk and sugar are essentially imported foods, whose price nevertheless falls within reach of the lower income groups. The position of rice, however, is an interesting one. Rice is not native to Nigeria and, as noted above, it does not occur in significant quantities in rural diets. Its occurrence in urban diets is associated with the fact that it is par excellence the food which is bought ready-cooked. For the food seller, its keeping quality in both raw and cooked states makes it an ideal commodity; for the customer, its taste is acceptable, it is less messy than other staples, and it has a certain amount of prestige. In the present survey, the majority of bought meals included rice; in only one group of families (see below) was rice cooked in the home.

Subdivision of those households surveyed according to their region of origin (Table 5) shows that many of the regional differences in rural diets are found also in their urban 
counterparts. The main similarities have been outlined above; one of the outstanding differences, however, is the relatively large amount of rice consumed in the households of Northern origin, and these were the only ones in which rice was cooked in the home. Comparison of the nutrient values of the urban and rural diets is not always possible owing to different methods of calculation, but for the majority of villages the nutrient values are higher than for the corresponding urban groups. The outstanding feature is that the nutrient values of diets of people of Western origin were lower than of those of similar economic level coming from other regions. On the other hand, mean weights of adults in the villages tended to be lower than those in Lagos, which suggests that the calorie expenditure in rural areas is greater than in the town.

The unequal distribution of food within the family noted among rural populations is at least as marked in the urban groups, with the consequence that the nutrient intake of children falls below recommended levels for a number of nutrients. Since the average adult diet (Table 3 ) tends to be lower, in relation to requirements, in calories than in protein, this disparity is even more marked in the children's diets; when these are grouped according to region of origin, it is evident that Western children in the lower income groups (Table 7) are subsisting on a very low level of nutrient intake. With such a degree of calorie restriction, it is inevitable that some of the protein will be utilized to provide energy. Miller \& Payne (1964) have proposed equations for calculation of this protein loss. Substituting the values for the 2- to 5year-old Western children referred to above (mean weight $12.0 \mathrm{~kg}$ ) in Miller \& Payne's equation (3), we obtain a value for net protein utilization of $0 \cdot 79$; from their equation (4) for the derivation of nitrogen balance (assuming a protein score of 60) we obtain a value of $97 \mathrm{mg} /$ day, indicating a precarious state of balance. In contrast, for the Northern children of the same age-group (mean weight $15.4 \mathrm{~kg}$ ) we obtain a value for nitrogen balance of $1210 \mathrm{mg} / \mathrm{day}$.

Under such circumstances, growth is inevitably retarded, and our values (Table 8) show that the mean weights of children tend to be below English averages, with those of Western children falling below those of other regions. In addition, the low level of intake of vitamins of the B group, notably of riboflavine, results in the appearance of angular stomatitis in a number of children. Signs of malnutrition were not seen in adults, but the difference in mean body-weights between the Westerners and those from other regions (Table 9) reflects the differences in their nutrient intakes. For lactating women, it is evident that, although food intake tends to be increased, the increase is not sufficient to maintain normal weight during lactation.

I am indebted to the Chief Medical Adviser to the Federal Government of Nigeria for permission to publish this paper. I am also grateful to Dr J. N. Rea and Mrs M. O. Olaniyan of the Institute of Child Health, Lagos, and to Mrs O. I. Amenechi of the Nutrition Service, for their help in the planning and execution of this survey. 


\section{REFERENCES}

British Medical Association (1950). Report of the Committee on Nutrition. London: British Medical Association.

Collis, W. R. F., Dema, 1. \& Omololu, A. (1962). Trop. geogr. Med. 14, 20 I

Ekpo, E. U. ( ( 964). In Seminar on Nutrition Education. Enugu: Ministry of Health (mimeo).

FAO (1957a). F.A.O. nutr. Stud. no. I5.

FAO (1957b). F.A.O. nutr. Stud. no. 16.

FAO (1962). F.A.O. nutr. Stud. no. 30.

Miller, D. S. \& Payne, P. R. (I964). Proc. Nutr. Soc. 23 , I I.

Nicol, B. M. (1959a). Br. F. Nutr. 13, 293.

Nicol, B. M. (1959b). Br. F. Nutr. т3, 307.

Tanner, J. M. (1958). In Modern Trends in Paediatrics. Second Series, p. 325. [A. Holzel and J. P. M. Tizard, editors.] London: Butterworths.

WHO (1963). Tech. Rep. Ser. Wld Hlth Org. no. 258. 